\title{
Determination of Fluoride in Coal Using Pyrohydrolysis for Analyte Separation
}

\author{
Valderi L. Dressler ${ }^{*, a}$, Dirce Pozebon ${ }^{b}$, Éder L. M. Flores $^{a}$, José N. G. Paniz $^{a}$ and Érico M. M. Flores ${ }^{a}$ \\ ${ }^{a}$ Departamento de Química, Universidade Federal de Santa Maria, Camobi, 97105-900 Santa Maria - RS, Brazil \\ ${ }^{b}$ Instituto de Química, Universidade Federal do Rio Grande do Sul, Av. Bento Gonçalves, 9.500, 91501-970 \\ Porto Alegre - RS, Brazil
}

\begin{abstract}
É proposto um método para a determinação de fluoreto em carvão mineral. O mesmo é baseado no emprego da pirohidrólise para a separação do fluoreto da amostra e posterior determinação do analito por potenciometria direta, com eletrodo íon seletivo. O sistema utilizado para a realização da pirohidrólise foi desenvolvido e a influência do $\mathrm{V}_{2} \mathrm{O}_{5}$ como catalisador na reação de pirohidrólise foi investigada, sendo verificado que o mesmo não influencia sobre a liberação do fluoreto presente na amostra. Amostras certificadas e não certificadas de carvão mineral foram analisadas. Resultados precisos (desvio padrão relativo inferior a 7\%) e exatos (recuperação do fluoreto de acordo com os valores certificados) foram obtidos. O limite de quantificação (LOQ) do método foi de 5,0 $\mu \mathrm{gF} / \mathrm{g}$ de amostra, usando $20 \mathrm{mg}$ de amostra e volume final de $10 \mathrm{~mL}$. A freqüência de análise foi de 5 amostras $\mathrm{h}^{-1}$.
\end{abstract}

A method for the determination of fluoride in coal using pyrohydrolysis for sample decomposition is proposed. An apparatus was constructed, and the influence of vanadium pentoxide $\left(\mathrm{V}_{2} \mathrm{O}_{5}\right)$ as a catalyst for the pyrohydrolysis reaction was investigated. It was verified that $\mathrm{V}_{2} \mathrm{O}_{5}$ does not influence the release of fluoride from coal. Certified and non-certified samples were analysed using an ion selective electrode (ISE) for analyte detection. Precise (RSD $<7 \%$ ) and accurate (recovery in accordance with certified values) results were obtained. The limit of quantification (LOQ) of the method was $5.0 \mu \mathrm{gF} / \mathrm{g}$ of sample, using $20 \mathrm{mg}$ of sample and a final dilution to $10 \mathrm{~mL}$. The sample frequency was 5 samples $\mathrm{h}^{-1}$.

Keywords: coal, fluoride, pyrohydrolysis, ion electrode, vanadium pentoxide, catalyst

\section{Introduction}

Fluorine is one of several trace elements receiving much attention owing to its possible harmful ecological effects. This element is considered essential to both plant and animal life at low concentrations but is toxic at high concentrations. The potential toxicity of fluorine has been classified as "high" for terrestrial life and "low" for aquatic life. ${ }^{1,2}$ Due to the high volatility of the element, the widespread world consumption of coal may result in significant fluorine emissions. ${ }^{2}$ From this point of view, it is important to establish accurate, precise and rapid methods for determination of this element.

With the exception of a few instrumental methods, ${ }^{2,3}$ the determination of fluoride in coal is carried out after sample dissolution. Most published methods related to

* e-mail: valdres@quimica.ufsm.br the determination of fluoride in solid samples thus involve distillation, pyrohydrolysis, alkaline fusion, combustion bomb or acid decomposition in a bomb, typically followed by spectrophotometric or potentiometric measurements. ${ }^{3,4}$ In some instances, these methods are complex and time consuming (mainly methods based on distillation and fusion), may give incomplete breakdown of fluorinecontaining compounds, analyte losses during the depressurisation of the bomb (decomposition in a combustion bomb), or by volatilisation (alkaline fusion), if the fusion temperature is not closely and accurately controlled. ${ }^{2}$

On the other hand, high temperature hydrolysis (pyrohydrolysis) quickly releases fluoride as hydrogen fluoride. The term pyrohydrolysis was adopted to describe hydrolytic reactions whose equilibrium constants and higher reaction rates seem to be favoured at higher temperatures. The pyrohydrolysis procedure for fluoride determination was first exploited by Warf and co-workers. ${ }^{5}$ 
In this procedure, steam was passed over a heated sample in a platinum apparatus and the volatile products of the pyrohydrolysis were condensed and titrated.

The general reaction of pyrohydrolysis is expressed by the following equation:

$\mathrm{MF}_{2 \mathrm{n}}+\mathrm{nH}_{2} \mathrm{O} \rightarrow \mathrm{MO}_{\mathrm{n}}+2 \mathrm{nHF}$

In the case of several fluorines, this reaction is slow and usually carried out at temperatures around $1000{ }^{\circ} \mathrm{C}$. However, the rate of the reaction is increased in the presence of some oxides, for instance, those of uranium, vanadium, aluminium and tungsten. ${ }^{6}$ In any case, an oxidant carrier gas, saturated with water vapour, is passed over a heated mixture of sample and catalyst, and the evolved hydrogen fluoride is collected in a dilute alkaline solution or simply condensed.

Pyrohydrolytic methods for decomposing the sample for fluoride determination have proved to be effective and reliable for fluorine compounds that are difficult to decompose by the fluorosilicic acid distillation method of Willard-Winter using perchloric, sulphuric or phosphoric acids. ${ }^{5}$ Therefore, the pyrohydrolytic method is especially useful for solid samples, as the fluorides can be separated directly without a preliminary fusion step or distillation. ${ }^{7}$ Since 1954, when pyrohydrolysis was first proposed by Warf et al. ${ }^{5}$ for analytical purposes, several modifications of the procedure have been used for volatilising fluoride, mainly from solid samples. ${ }^{3,4}$ The relatively high temperature and the known corrosive action of hydrofluoric acid solutions on metal and glass dictated the use of extremely resistant structural materials, such as quartz, platinum, stainless steel, nickel, porcelain, fused silica, and ceramics. Various devices, employing heating accessories, such as burners and different furnaces (microchemical, resistance and induction furnaces), have been used in pyrohydrolysis. ${ }^{8,9}$

Regarding catalysts, vanadium(V) oxide has been widely employed as one of the most active. However, in some cases inaccurate results were obtained in fluoride determinations using acidimetry, as some vanadium(V) oxide was carried along the reaction tube, increasing the consumption of the standard alkaline solution. ${ }^{8}$ Other workers ${ }^{6,8,10}$ comment that vanadium(V) oxide was used without complications, employing spectrophotometry, titrimetry with thorium nitrate, potentiometry with a fluoride-ion selective electrode (ISE), or ion chromatography for the fluoride determinations. Some methods employed mixtures of vanadium $(\mathrm{V})$ oxide with other substances (bismuth oxide, tungsten oxide, molybdenum oxide, silicon oxide, nickel, iron, tin, or potassium dihydrogen phosphate). ${ }^{11-14}$ These mixtures can be prepared in bulk or mixed with the sample as required.

Other proposed methods combine fusion of the samples with several fluxes, such as $\mathrm{Na}_{2} \mathrm{CO}_{3}, \mathrm{Na}_{2} \mathrm{CO}_{3} / \mathrm{K}_{2} \mathrm{CO}_{3}, \mathrm{Na}_{2} \mathrm{O}_{2} /$ $\mathrm{NaOH}$, and $\mathrm{NaOH}$, followed by dissolution in acid and potentiometric fluoride determination. These methods offer significant improvements over the steam distillation methods employing titration (for higher fluoride contents) or spectrophotometry, but some separation (e.g. leaching) steps are required, which restrict the handling of a large number of samples. ${ }^{15-17}$

The main purposes of this work were to investigate vanadium(V) oxide as a catalyst in the pyrohydrolysis of coal for fluoride determination using ISE, and the construction of a simple apparatus to separate the analyte from the sample matrix.

\section{Experimental}

\section{Pyrohydrolysis apparatus}

The pyrohydrolysis apparatus (Figure 1) was made in house. It consists basically of a steam generator unit, a heater, a condenser, a collector for the fluoride distillate, and a pyrohydrolysis unit consisting of a tube and a boat, both of quartz. The steam generator is a borosilicate Erlenmeyer flask containing water which is heated by an immersed heating element. This flask is adapted to a flow meter and to a water trap via two polytetrafluoroethylene (PTFE) tubes which are connected to the flask through a silicone rubber stopper. A small air pump is used in order to pass the steam through the pyrohydrolysis unit and the air flow is controlled by a flow meter. The water trap, also

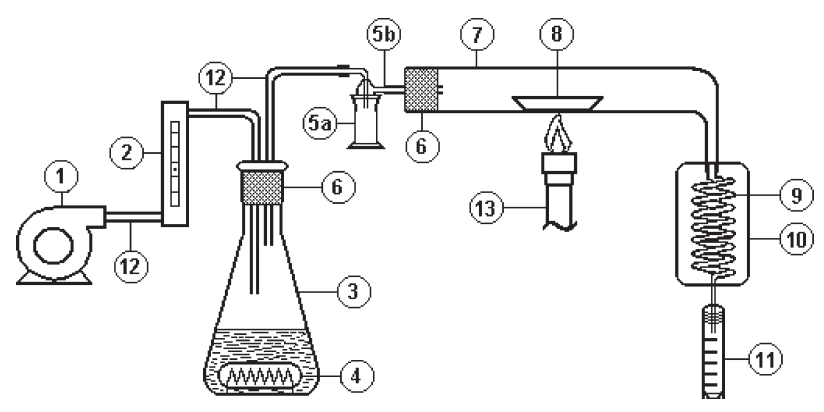

Figure 1. Apparatus for separating fluoride by pyrohydrolysis. 1: air pump; 2: flow meter (100 to $1000 \mathrm{~mL} \mathrm{~min}^{-1}$ ); 3: $500 \mathrm{~mL}$ Erlenmeyer flask containing water; 4 : heating element; $5 \mathrm{a}$ : water trap (5 $\mathrm{mL})$ and $5 \mathrm{~b}$ : adapter $(\mathrm{L}=2 \mathrm{~cm}$, i.d. $=0.3 \mathrm{~cm}) ; 6$ : silicone rubber; 7: quartz tube $(\mathrm{L}=15 \mathrm{~cm}$, i.d. $=2 \mathrm{~cm})$; 8 : quartz boat $(\mathrm{L}=2 \mathrm{~cm}$, width $=1 \mathrm{~cm}$, depth $=0.5 \mathrm{~cm}$ ); 9: condenser (PTFE tube, $\mathrm{L}=50 \mathrm{~cm}$, i.d. $=0.2 \mathrm{~cm}) ; 10$ : ice bath $(500 \mathrm{~mL}$ flask, filled with ice $) ; 11$ : graduated polypropylene vial $(15 \mathrm{~mL}) ; 12$ : PTFE tubes $(\mathrm{L}=20 \mathrm{~cm}$, i.d. $=0.5$ $\mathrm{cm})$; 13: burner. 
made of glass, avoids the introduction of water droplets into the pyrohydrolysis unit. This trap is adapted to the quartz tube of the pyrohydrolysis unit through a silicone rubber stopper. The pyrohydrolysis unit is heated by a burner. The outlet of the quartz tube is connected to a PTFE tube which is immersed in an ice bath in order to condense the analyte vapour, avoiding loss of HF. The condensed solution containing the analyte is collected in a $15 \mathrm{~mL}$ graduated polypropylene vial.

\section{Reagents and solutions}

All solutions were prepared in distilled/deionized water (18 $\mathrm{M} \Omega \mathrm{cm})$. The chemicals were of analytical grade quality.

Vanadium Pentoxide. Ammonium vanadate $\left(\mathrm{NH}_{4} \mathrm{VO}_{3}\right)$ from Merck (Darmstadt, Germany) was heated in a platinum crucible at $500-550^{\circ} \mathrm{C}$ until the product obtained $\left(\mathrm{V}_{2} \mathrm{O}_{5}\right)$ became dark red (ca. $4 \mathrm{~h}){ }^{6}$

TISAB (Total Ionic Strength Adjuster Buffer). $58 \mathrm{~g}$ of sodium chloride (Merck), $4 \mathrm{~g}$ of 1,2-cyclohexyldiaminetetraacetic acid (Merck), and $57 \mathrm{~mL}$ of acetic acid (Merck) were dissolved in $500 \mathrm{~mL}$ of water. After dissolution the $\mathrm{pH}$ was adjusted to $5.2-5.5$ with a $20 \% \mathrm{~m} / \mathrm{v}$ sodium hydroxide solution and the volume was completed to $1000 \mathrm{~mL}$ with water.

Fluoride stock solution. A $1000 \mathrm{mg} \mathrm{L}^{-1}$ fluoride solution was prepared from a Titrisol ${ }^{\circledR}$ ampoule (Merck). Fluoride calibration solutions in the range of 0.25 to $10.0 \mathrm{mg} \mathrm{L}^{-1}$ were prepared by serial dilutions of the stock solution with water. Finally, equal volumes of each calibration solution and the TISAB solution were mixed.

\section{Procedure}

The amount of sample used ranged from 5 to $120 \mathrm{mg}$, previously mixed with the catalyst (when catalyst was used). The catalyst/sample ratio was increased from 0 to 4 $(\mathrm{m} / \mathrm{m})$. For sample pyrohydrolisation using the apparatus shown in Figure 1, the boat (8) containing the sample or the catalyst/sample mixture was introduced into the quartz tube (7). Subsequently, the silicone rubber stopper (6) was inserted into the quartz tube (7), and the sample was pyrohydrolysed for $10 \mathrm{~min}$ at $1150-1170{ }^{\circ} \mathrm{C}$ using an air flow rate of $300 \mathrm{~mL} \mathrm{~min}^{-1}$. This temperature (measured with a thermocouple) was achieved by positioning the burner (13) ca. $2.5 \mathrm{~cm}$ under the quartz tube (7). Once sample pyrohydrolysis was concluded, the vial (11) containing the condensate was filled to $5 \mathrm{~mL}$ with water. Then, $5 \mathrm{~mL}$ of TISAB solution was added and the fluoride content was measured potentiometrically, using a potentiometer (HANNA instruments) equipped with a fluoride ISE electrode (Orion - 9609BN). The analyte concentration was measured against an analytical curve prepared using the previously described calibration solutions. Either a boat containing $\mathrm{V}_{2} \mathrm{O}_{5}$ or only the empty boat were used as sample blanks, which were run prior to the sample.

All vials and flasks were washed with water prior to use. The boats were also soaked in a 1+1 nitric acid/water solution for $10 \mathrm{~min}$. Finally, they were rinsed with water and dried. Whenever necessary, they were also cleaned mechanically by using a metal spatula.

\section{Samples}

Coal samples from NIST (National Institute of Standards and Technology - NIST 1632b and NIST 1635), BCR (Bureau Communautaire de Référence - Community Bureau of Reference - now Standards Measurement and Testing Programme - BCR 40) and SARM (South Africa Bureau of Standards, SARM 19 and SARM 20) were analysed. A non-certified coal sample from Candiota (Rio Grande do Sul, Brazil) was also analysed. The samples from NIST, BCR and SARM were analysed as received, except for being dried according to the procedures recommended on the certificates. The real sample was ground in a mill and then in an agate mortar, in order to obtain a $<200$ mesh granulometry. All samples or the catalyst/sample mixtures were weighed directly into the boat and submitted to the pyrohydrolysis process.

\section{Results and Discussion}

\section{Method development}

Initially, the pyrohydrolysis apparatus (Figure 1) was constructed and tests were carried out for optimising the temperature and the air flow rate. The temperature inside the pyrohydrolysis unit was measured (both on the internal wall of the quartz tube and on the wall of the sample boat), relative to the distance from the burner. The highest temperature $\left(c a .1170^{\circ} \mathrm{C}\right)$ was measured at $c a .2 .5 \mathrm{~cm}$ above the burner, this distance being set for further measurements. As expected, the temperature on the internal wall of the quartz tube was higher $\left(\mathrm{ca} .1170{ }^{\circ} \mathrm{C}\right)$ than on the wall of the boat $\left(\mathrm{ca} .1050^{\circ} \mathrm{C}\right)$. However, the boat was used as it is easier to handle the sample, mainly when catalyst was used.

The temperature variation as a function of the air flow rate (in the range of 100 to $400 \mathrm{~mL} \mathrm{~min}^{-1}$ ) through the pyrohydrolysis unit was also studied and it was observed that this variation was small. A low air flow rate of $200 \mathrm{~mL}$ 
$\min ^{-1}$ was enough for quantitative recovery of fluoride. Nevertheless, and to guarantee a fast and safe transport of the analyte, probably as hydrogen fluoride, from the quartz tube to the condenser, an air flow rate of $300 \mathrm{~mL} \mathrm{~min}^{-1}$ was established.

The catalyst/sample ratio was also investigated. As shown in Figure 2, fluoride recovery from coal is quantitative even in the absence of $\mathrm{V}_{2} \mathrm{O}_{5}$. Finally, the time of pyrohydrolysis was optimised, and the results are shown in Figure 3. At least $7.5 \mathrm{~min}$ are necessary to obtain $>97 \%$ analyte recovery. Thus, a time interval of $10 \mathrm{~min}$ was established for further measurements, in order to achieve complete fluoride release from the sample.

For some coal samples, such as NIST 1632b, a greasy residue (seeming to be an oil) remained in the pyro-

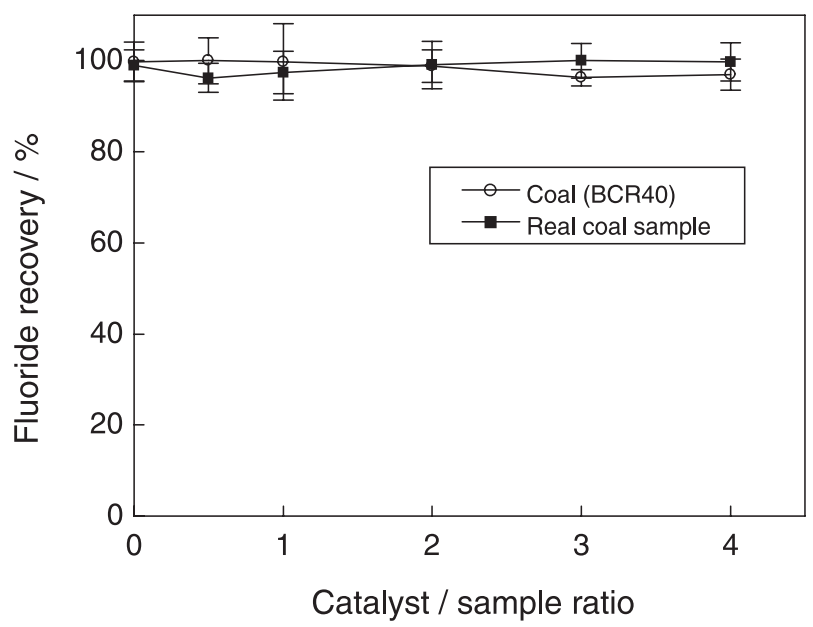

Figure 2. Influence of $\mathrm{V}_{2} \mathrm{O}_{5}$ on fluoride recovery $(\mathrm{n}=5)$. Sample mass: $50 \mathrm{mg}$; time of pyrohydrolysis: $10 \mathrm{~min}$; pyrohydrolysis temperature: $1150{ }^{\circ} \mathrm{C}$; and air flow rate: $300 \mathrm{~mL} \mathrm{~min}^{-1}$.

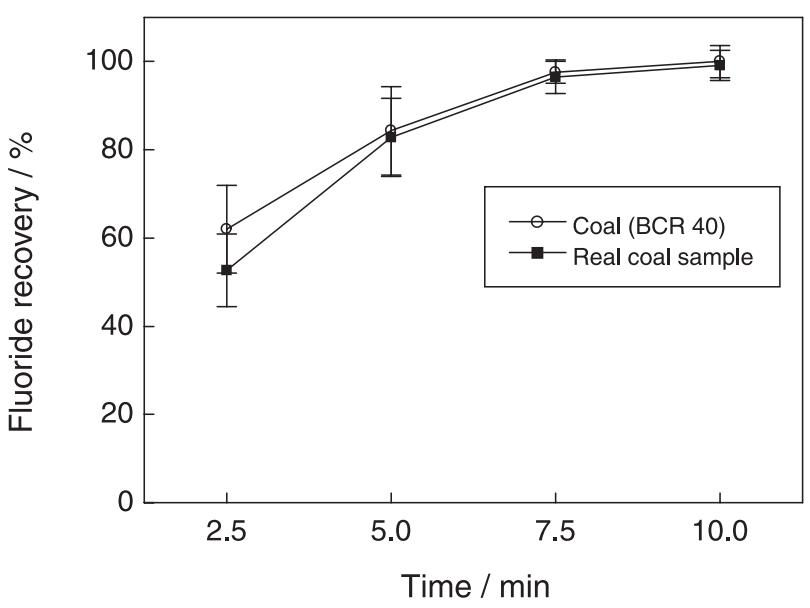

Figure 3. Fluoride recovery of as a function of the time of heating $(\mathrm{n}=5)$. Sample amount: $50 \mathrm{mg}(\mathrm{BCR} 40)$; pyrohydrolysis temperature: $1150{ }^{\circ} \mathrm{C}$; and air flow rate: $300 \mathrm{~mL} \mathrm{~min}^{-1}$. hydrolysis unit. This was also observed in the vial containing the condensate, but it did not affect fluoride recovery.

\section{Analytical results}

The analytical parameters of the procedure are shown in Table 1. The precision is good (relative standard deviation - RSD $<7 \%$ ) and the limit of quantification (LOQ) is considerably lower than the fluoride concentration in the analysed samples (Table 2), indicating the feasibility of the proposed method. The LOQ was calculated considering the low Nernstian response limit of the electrode, $0.25 \mathrm{mg} \mathrm{L}^{-1}$ of fluoride. ${ }^{18}$ The sample amount $(5 \mathrm{mg})$ and the final dilution $(10 \mathrm{~mL})$ of the condensate were computed in order to obtain the LOQ. Although the sample amount ranged from 5 to $120 \mathrm{mg}$, it is possible to use higher amounts. In comparison to other methods, the sampling frequency is also good (5 samples per hour). Analyte separation is much faster than in most recommended procedures as, for instance, distillation or alkaline fusion. ${ }^{19}$

Concentrations of fluoride in coals from different origins range from 20 to $500 \mu \mathrm{g} \mathrm{g}^{-1}$, however higher values

Table 1. Characteristics of the proposed method

\begin{tabular}{|c|c|}
\hline Air flow rate $/ \mathrm{mL} \mathrm{min}^{-1}$ & 300 \\
\hline Pyrohydrolysis temperature $/{ }^{\circ} \mathrm{C}$ & $1050-1170$ \\
\hline Extraction time / min & 10 \\
\hline Sample amount / mg & $5-120$ \\
\hline Volume of condensed solution / $\mathrm{mL}$ & ca. 4.0 \\
\hline $\begin{array}{l}\text { Relative standard deviation } \\
(\mathrm{n}=10) / \%^{\mathrm{a}}\end{array}$ & $<7.0$ \\
\hline Limit of quantification $/ \mu \mathrm{g} \mathrm{g}^{-1}$ & 5.0 \\
\hline Sampling frequency $/ \mathrm{h}^{-1}$ & 5 \\
\hline Analytical curve $\mathrm{e}^{\mathrm{b}}$ & $\mathrm{y}=-0.02251 \mathrm{x}+1.95718$ \\
\hline $\begin{array}{l}\text { Correlation coefficient of the } \\
\text { analytical curve }\left(\mathrm{r}^{2}\right)\end{array}$ & 0.9988 \\
\hline
\end{tabular}

Table 2. Determination of fluoride in coal samples ( $n=5$; uncertainties are the standard deviations)

\begin{tabular}{lcc}
\hline Sample & $\begin{array}{c}\text { Determined } \\
\left(\mu \mathrm{g} \mathrm{g}^{-1}\right)\end{array}$ & $\begin{array}{c}\text { Certified } \\
\left(\mu \mathrm{g} \mathrm{g}^{-1}\right)\end{array}$ \\
\hline NIST 1632b (coal) & $40.0 \pm 1.7$ & $41.7 \pm 3.2$ \\
NIST 1635 (coal) & $27.3 \pm 1.1$ & $25.9 \pm 3.3$ \\
BCR 40 (coal) & $119.7 \pm 5.4$ & $111.4 \pm 8.5$ \\
SARM 19 (coal) & $93.5 \pm 5.9$ & - \\
SARM 20 (coal) & $125.8 \pm 8.4$ & $>120^{\mathrm{a}} ; 142^{\mathrm{b}}$ \\
Real coal sample & $404.2 \pm 4.8$ & - \\
NIST 1633b (coal fly ash) & $121.3 \pm 5.0$ & - \\
\hline
\end{tabular}

a Indicated by I. Roelandts, et al. ${ }^{3}$; ${ }^{\mathrm{b}}$ Determined by Conrad and Brownlee ${ }^{14}$. 
have also been found. ${ }^{4,20}$ Thus, the high fluoride concentration found in a real coal sample (Table 2) may be attributed to the high ash content of this sample. According to Finkelman, ${ }^{20}$ fluoride in most coals is predominantly associated with the mineral matter, mainly fluorapatite, but other minerals such as fluorite, biotite, amphiboles, micas, and perhaps tourmaline, may be present as finely divided particles or larger discrete particles containing fluorine. There is also the possibility of some organic fluorine compounds.

\section{Conclusions}

It is possible to determine fluoride in mineral coal with the proposed method and apparatus. It was shown that it is not necessary to use a catalyst for pyrohydrolysis reactions of mineral coal samples. With this pyrohydrolytic method, the analysis is rapid in comparison to other methods using distillation or alkaline fusion, its implementation is easy, and the fluoride can be separated from the complex matrix of a solid sample. Precise and accurate results are obtained.

\section{Acknowledgements}

This work was supported by grants from FAPERGS (Fundação de Amparo à Pesquisa do Estado do Rio Grande do Sul), Brazil.

\section{References}

1. Environmental Health Criteria 36; Fluorine and Fluorides, World Health Organization; Geneve, Italy, 1984.

2. Bettinelli, M.; Analyst 1983, 108, 404.
3. Roelandts, I.; Robaye, G.; Delbrouck-Habaru, J.M.; Weber, G.; Talanta 1996, 43, 439.

4. Quevauviller, P.; Van der Staak, H.; Van Loenen, D.; Lingerak, W.; Griepink, B.; Fresenius J. Anal. Chem. 1994, 350, 101.

5. Warf, J.C.; Cline, W.D.; Tevebaugh, R.D.; Anal. Chem. 1954, 26, 342.

6. Newman, A.C.D.; Analyst 1968, 93, 827.

7. Surak, J.G.; Fisher D.J.; Burros, C.L.; Bate, L.C.; Anal. Chem. 1960, 32, 117.

8. Nebesar, B.; Talanta 1978, 25, 185.

9. Rice, T.D.; Talanta 1988, 35, 173.

10. Whitehead, D.; Thomas, J.E.; Anal. Chem. 1985, 57, 2421.

11. Clements, R.L.; Sergeant, G.A.; Webb, P.J.; Analyst 1971, 96, 51.

12. Evans, K.L.; Tarter, J.G.; Moore, C.B.; Anal. Chem. 1981, 53, 925.

13. Doolan, K.J.; Anal. Chim. Acta 1987, 202, 61.

14. Conrad, V.B.; Brownlee, W.D.; Anal. Chem. 1988, 60, 365.

15. Van Leuven, H.C.E.; Rotscheid, G.J.; Buis, W.J.; Fresenius Z. Anal. Chem. 1979, 296, 36.

16. Bodkin, J.B.; Analyst 1977, 102, 409.

17. Adelantado, J.V.G.; Martinez, V.P. Moreno, A.C.; Reig, F.B.; Talanta 1985, 32, 224.

18. Evans, A.; Potentiometry and Ion Selective Electrodes. Analytical Chemistry by Open Learning (ACOL), Wiley: Chichester, UK, 1991.

19. http://energy.er.usgs.gov/products/papers/B1823/index.htm, accessed on July 2002.

20. Finkelman, R.B. In Environmental Aspects of Trace Elements in Coal; Swaine, D.J.; Goodarzi, F. eds.; Kluwer Academic Publishers: Amsterdam, the Netherlands, 1995, pp. 24-50.

Received: October 19, 2002 Published on the web: April 17, 2003 